\title{
MEMOIR OF SUMNER WEBSTER CUSHING
}

\section{Ellsworth Huntington}

To cite this article: Ellsworth Huntington (1921) MEMOIR OF SUMNER WEBSTER CUSHING, Annals of the Association of American Geographers, 11:1, 109-111, DOI: 10.1080/00045602109357024

To link to this article: http://dx.doi.org/10.1080/00045602109357024

曲 Published online: 19 Feb 2009.

Submit your article to this journal $\pi$

Џ Article views: 3

Q View related articles $\widetilde{ }$

4 Citing articles: 1 View citing articles 


\section{MEMOIR OF SUMNER WEBSTER CUSHING ELLSWORTH HUNTINGTON}

Geography and mathematics are the only sciences which enter extensively into education at all ages. In mathematics the logical mode of procedure from the simple to the complex is so thoroughly established that it has ceased to be a problem. Geography, however, is still growing not only at the top, as in mathematics, but in every direction. Many of the new ideas of the most advanced investigators at once become a part of elementary education, as happened, for example, with the concept of cycles of youth, maturity, and old age. Because the subject is in such a state of flux there is grave danger of mistakes; the elementary teachers are often carried away by a laudable but mistaken enthusiasm for the new, even when it is far too mature for their pupils, while the advanced teacher is too elementary. Hence, among the many and pressing needs of modern geography one of the greatest is men who know the whole range of the subject and can see it with the eyes of the eight-year old child, the college student, the teacher, and the highly trained investigator.

Sumner Webster Cushing was one of the few men who had this power of seeing geography with the eyes of all ages. He was fitted to do this by training and occupation, by scientific achievement, and by personality. To begin with training and occupation, Mr. Cushing was born in Norwell, Massachusetts, December 30, 1879, the son of Webster A. and Amanda Cushing. He was graduated from the Brockton High School and the State Normal School at Bridgewater. In 1903, after a two years' course at Harvard University, he received the degree of B.S. He then taught, in successive years, the subjects of science, mathematics, and physical geography in the high schools of Wakefield, Mass, Waterbury, Conn., and Providence, R. I. While in Providence he studied at Brown University and received his master's degree.

In 1907 he became the head of the geography department at the State Normal School in Salem, Mass. To quote from Mr. Pitman, principal of that school, "In addition to his classes in geography in the normal school, he supervised the work in the training school, made out a course of study for the guidance of the student teachers and the supervisors of the grades, and kept in close touch with the work of the children. His field trips and excursions to industrial plants added greatly to the interest in the subject both among the children and among the students in the normal school. His students will never forget the delightful trips to Devereux Beach, nor the more strenuous excursions devoted to tracing the course of Forest River. He was untiring in his plans to present subjects of general interest to the 
entire school by lectures, lantern slides, and motion pictures. In every possible way he strove to make the subject of geography alive and to show its importance in understanding the trend of civilization. $\mathrm{He}$ succeeded to an unusual degree, for his students speak of him as a wonderful teacher." In addition to his work at Salem, Mr. Cushing taught geography at Wellesley College from 1911 to 1913, and gave summer courses at several universities-Illinois, 1910 and 1914; Columbia, 1912, and Miami, 1917. He was also on various committees of the Massachusetts State Board of Education and the National Council of Geography Teachers for the preparation of courses of study in elementary, high, and normal schools. Thus in both his education and his teaching Mr. Cushing came in contact with every phase of geographical education.

Mr. Cushing's career as a scientific investigator began with his attendance at the summer session at Harvard in 1907. As Professor Davis puts it: "A praiseworthy ambition to advance in his chosen science led him to spend the next summer in France, studying the Central Plateau with his former Harvard professors, W. M. Davis and D. W. Johnson. Similarly his vacation in 1909 was spent in an examination of the coastal features of Maine, during which he traveled in and out along the coast some 1500 miles. His statement of the results of this work before the Geological Conference at Harvard led to his securing a Sheldon travelling fellowship from the Harvard Graduate School, which enabled him, while on leave of absence from Salem, to visit India in 1910-11, for the investigation of a special geographical problem in the region of Madras. His report upon this problem, "The East Coast of India," presented at a meeting of the Association of American Geographers in 1911, attracted highly favorable notice as far and away superior to any previous description of the Madras coast. Its publication at once gave him an assured position as a professional geographer." Later work on Japan and New England, and upon many problems in commercial and industrial geography confirmed this position.

In his personal relations Mr. Cushing was at his best among his students. There he lost a certain shy reserve which sometimes partly concealed a really remarkable sweetness of disposition. When he came into intimate contact with his fellow geographers, as he did, for example, during the Transcontinental Excursion under the auspices of the American Geographical Society in 19.12, he was revealed as a man of most genial sympathies, unusual courtesy and great modesty, with decided opinions but holding them in the true spirit of humility which is ready to acknowledge mistakes and profit by the advice and experience of others. That excursion broadened him greatly, as did his marriage in 1913 to Miss Frances B. Deane. She had been a teacher of history in the Salem Normal School, and her historical knowledge and 
literary ability were a great help to Mr. Cushing. Of even more importance was the fact that she strengthened his confidence in his own powers, for he often underrated himself. Another experience which had a similar broadening and strengthening effect was a year's service as Captain in the Military Intelligence Division of the General Staff in Washington, from July, 1918, to July, 1919. As General Churchill, his chief, well said, he left behind him " a record of marked ability, and fine devotion to duty. He endeared himself to all his associates."

In Mr. Cushing's own opinion all his work up to about 1914 was merely preparation for his great life purpose. That purpose was to help create the right relation between geographical research and teaching, and between the teaching in one stage of education and another. Most of his program to this end was perforce left unfinished. Judging by his articles and addresses and especially by his phenomenal success in inspiring normal school students and elementary teachers, his projected book on the teaching of geography and the use of problems would have marked an important step toward the goal of satisfactory geographical teaching. Something of its character may be judged from a "Teacher's Manual of Geography for Grades VII and VIII," which was distributed broadcast by the Massachusetts State Board of Education and for which there was a great demand in other states. Although the Manual was ostensibly prepared by a committee, Mr. Cushing was the moving spirit, and the ideas and methods of the book are largely his. Another place where Mr. Cushing's educational ideas are firmly embedded is in the "Principles of Human Geography," of which he was joint author with the present biographer. To that book, which unfortunately did not appear until after his death, Mr. Cushing contributed the major part of whaterer pedagogical value it may have. Another joint book, "Commercial and Industrial Geography," was nearly completed at the time of Mr. Cushing's death. To this he contributed the general plan, the method of presentation, and a large share of the text.

In all his work Mr. Cushing insisted first on absolute accuracy, for he was supremely truthful. He also insisted on orderliness, and on the idea that the mind of the student must work with that of the teacher. It is most impressive to hear his former pupils say, "Mr. Cushing made me think of that." He put his mark on his students and all who came in close contact with him because of his enthusiasm, for above all things he was an enthusiast. His enthusiasm was not merely for geography nor for teaching, but for the right relation of the two. His death leaves uncompleted a great piece of work for which he possessed a rare training. His sympathetic personality was fast making that training most effective in bridging the gap between the leaders of scientific investigation and the teachers through whom geography filters down into the common consciousness of mankind. 